\title{
Bowels and Urine Odors and Its Solutions
}

\author{
Pramod Stephen* \\ Life Member of Swadeshi Science Movement New Delhi, India
}

*Corresponding author: Pramod Stephen, Life Member of Swadeshi Science Movement New Delhi, India

\section{Opinion}

From the beginning time people go for bowel outside in the fields and when he was doing bowel that time how much time he spends that place he must live in the environments of the bowel odor. And till now after many improvements of toilets we must live in odor of poop in our toilets. we use perfume detergent cake and any kind of chemicals to remove odor, but odor mixed with perfume or chemical and disturb our nose to brain and our mood become distress. and when our brain gets disturb then our metabolic process is also disturbing. Poop odor spread soon after and its cover near about 5 to 8 feet diameters within 30 second and by smell flies and other insects attack the night soil. because it is good food for them. By the odor of bowel, we can get air borne diseases and other diseases like hepatitis, e-coli, dysentery viral infection, cholera diarrhea etc same time our faces contain many kinds of egg of worms and it is possible to get water borne diseases. odor of bowel is very slow poison because it contains sulfur compound, hydrogen sulfide, I bilirubin, biliverdin, various salt, Harmons, carbohydrates, fatty acid nitrogen, phosphorus and un digested food particles these are same compound that are responsible for odor of flatulence.

Urine is also waste product by human as well as creatures body. It contains water bilirubin various salt nitrogen phosphorus ammonia and some acid etc. At the time of disease like albumin diabetes jaundice and other diseases it contains different things. It has specific smell but smell and color of urine always changing and its gravity. When we drink more water the smell of urine is less, and color is less and if we drink less water than smell is more or hard and color is yellow and sometime radish. That time we get burning sensation in urination. When any creature get infection then it contains virus, Bactria, and other kind of germs also. I heard by many people in India I cross the urination and I got burning sensation in urine some told me by cross the urination place and, I got fever.

If people use one place for urination, then at the time of crossing that place it is very difficult to tolerate smell. So many people avoid going for urination but same time it is problem to controls and people go unwillingly in urinals because urination force is very bad for our internal gland body and mind that time, we fell fully discomfort. Most of the public urinal where is no proper maintenance and no proper drainage then we see that urine collected near the urinals then we find cloudy particles maggots and other specific species in the collected urine. I show many places bee also comes some time near the urinals. I show much kind of fungus clots in the urinal pot.

For good health and protect people from the diseases, Smell and gas of toilets and urinal is a big problem in everywhere of the world till now the method is popular is septic tanks, pits and two-hole pits and it is individual base, and community base and it is costly smelly and problem to remove night soil and throwing place. And gas produce by the septic tank pits its harm the human environments as well as earth. So, my plan is for night soil that we can put pipe for night soil to attaché in every home and through pipe its goes to bio gas digester and we must make three parts in the digester to make night soil in complete manure. Than we save land, time, health, environment and earth. I design an odor free full hygienic water less toilets and urinal it can be use in homes, hotels and public toilets. 
(C) This work is licensed under Creative

To Submit Your Article Click Here: Submit Article

DOI: $10.32474 / A D 0.2019 .01 .000125$

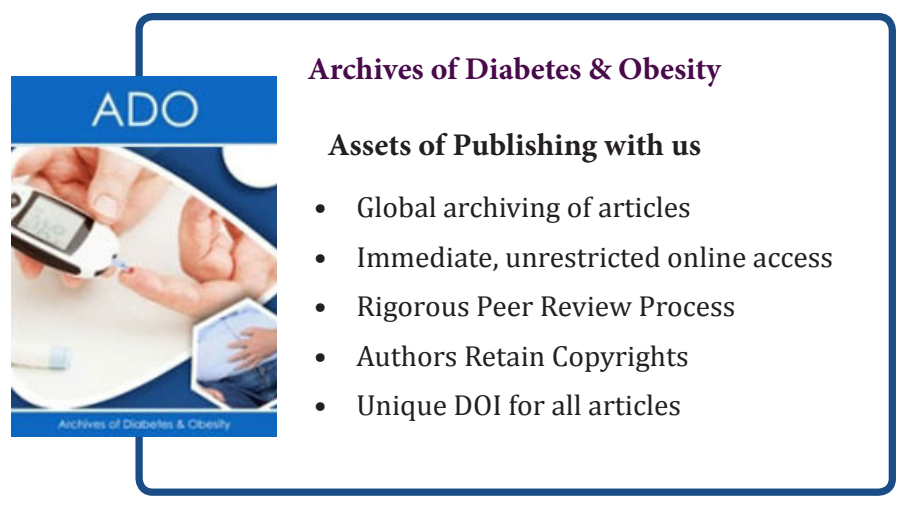

